\title{
Criminal Disparity in Law Enforcement to the Performers of Judi Togel in Simalungun Court State
}

\author{
Mariah SM Purba ${ }^{1}$, Anita Purba ${ }^{2}$ \\ ${ }^{1,2}$ Universitas Simalungun, Indonesia \\ mariapurba777@gmail.com,anitapurba@yahoo.co.id
}

\begin{abstract}
Gambling cases, especially lottery gambling, are a type of gambling that is rife in society. Courts are the last bastion for attendance seekers. Justice is not merely a place to punish but to get justice. However, the fact is that there are disparities in court decisions on the same case, namely lottery gambling at the Simalungun District Court. As for the problem is: whyCriminal disparities occur in terms of law enforcement against lottery gambling perpetrators at the Simalungun District Court and what efforts that can be made so that there is no disparity in decisions in lottery gambling cases. The research used is juridical legal research, research on laws whose position is the norm, namely the provisions of gambling crimes as regulated in the Criminal Code. Where the imposition of crimes against the same article is inconsistent, there are even disparities.
\end{abstract}

\section{Keywords}

Disparity; law

enforcement; lottery

gambling

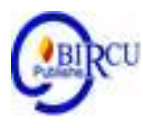

\section{Introduction}

Gambling is a societal disease that is very difficult to eradicate. Starting from the lower class economy level to the upper class economy level can gamble. The definition of gambling according to the Big Indonesian Dictionary is a game using money or valuables as a bet (such as playing dice, cards). Gambling in terms is a deliberate betting of a value by realizing the risk of certain expectations on events of events, games and games that have no or uncertain outcome. There are several types of gambling that are often carried out in the midst of society, including: gambling by playing cards, gambling by playing dice and gambling by guessing numbers or better known as lottery gambling (dark toto).

The game of gambling dexterity has damaged the mentality of the player so that the king's son willingly risked anything in the game even though he has lost the game, it has made him curious so that he constantly increases his stakes in the gambling game. (Marsella and Dian)

The principle of gambling in general is the same, namely, aiming to get a profit if you win the bet. In Simalungun Regency, one type of gambling that is often done by the community is lottery gambling. Lottery gambling is gambling by guessing the numbers that come out on certain days depending on the type of lottery gambling. The types of lottery gambling in Simalungun include: Kim Hong Kong lottery gambling, gambling is carried out every night from Sunday to Saturday at 23.00 every night. Whereas for Singapore lottery gambling, the draw is carried out every Sunday, Monday, Wednesday, Thursday and Saturday at 16.30 each. Each correct number is guessed and the calculation varies according to the number of correct numbers that are guessed.

The prizes obtained from this lottery gambling vary based on the number of numbers that are guessed correctly. For two (2) numbers guessed correctly, a prize of Rp. $65,000,000$ (sixty five thousand rupiah), (3) three numbers correctly guessed will receive a prize of Rp. 450,000. (Four hundred and fifty thousand rupiah), and every four (4) numbers 
guessed correctly will receive a prize of Rp. 2,500,000., (Two million five hundred thousand rupiah). Meanwhile, the price of each pair of numbers ordered or purchased by the buyer is Rp. 1000., (one thousand rupiah). With a relatively cheap purchase price and a rather lucrative prize offer is one of the causes of the rampant lottery gambling gambling.

At first before the rise of cell phones (HP), the purchase of lottery gambling was done manually where the buyer would order the number to be purchased from the seller. As proof of purchase, the seller will make on a piece of paper the buyer's guess, and at that time the buyer will pay an amount according to the number of orders he ordered. At the time of manual purchase, evidence in court is paper in the form of guessed figures and money.However, with the widespread use of mobile phones, at this time the procedure for purchasing lottery can be done by means of short messages via SMS. The way this is done is where the buyer will buy the lottery by typing the message number and sending it to the seller.Payments are still made at that time or before the time the lottery number is issued. USMS is proof of lottery purchase. So that at this stage there is also a change in the evidence submitted in court, in the form of money and confiscated cell phones to show the numbers ordered or purchased which are sent by the buyer to the seller via SMS short messages.

Gambling is very difficult to eradicate, because gambling is already a social disease. The development of information technology has also contributed to the increasing popularity of gambling and the increasing number of types of gambling. The consequences of gambling for society are always bad. Therefore, gambling must be eradicated and taken firmly. However, in its eradication, there is injustice for the lottery gambling perpetrators.

When viewed with the naked eye, almost every week at the Simalungun District Court there are trials with gambling cases, especially lottery gambling. Law enforcement in the handling of lottery gambling at the Simalungun District Court when viewed from the severity of the court decisions are still very diverse, where there is a very significant comparison of court decisions between the lightest to the most severe, in other words there are disparities in the verdict of lottery gambling in court Negeri Simalungun. Of course, the article under suspicion is the same article.

The problems studied are:

1) Why is there a disparity in punishment in terms of law enforcement against lottery gambling perpetrators at the Simalungun District Court?

2) What efforts can be made to avoid disparities in decisions regarding lottery gambling cases?

\section{Research Methods}

Research aims to reveal the truth in a systematic, methodological and consistent manner. Through the research process, analysis and construction were carried out on the data that had been collected and processed. Research is a (scientific) tool for the development of science and technology, so the research methodology is the main source and this does not always mean that the methodologies used by various sciences will be completely different. Legal research is also a process to determine legal rules, legal principles, and legal doctrines in order to address legal issues at hand. .

This type of research used in this research is normative legal research. Normative legal research is research on the law whose position is as a norm, namely the provisions of gambling crimes as regulated in the Criminal Code. Where the imposition of crimes against the same article is inconsistent, there are even disparities. 
In normative legal research, library material is the main data classified as secondary data. Secondary data is data obtained through library materials.

\section{Results and Discussion}

Court is the last bastion for justice seekers to get justice. Court is not a place of punishment but a place of people seeking justice. It is proper for every perpetrator of violation of the law to be sanctioned. One of the sanctions for perpetrators who violate the law is imprisonment which is obtained through a court decision.

One of the acts that violates the law in this case the Criminal Law (Law Number 73 of 19580 is gambling games. Gambling cases at the Simalungun District Court are almost always there. However, there are disparities or very striking differences in the range of decisions on the same case. .

Gambling provisions in the Criminal Code are regulated in Article 303 and Article 303 Bis KUH Pidana. Law enforcement is a system in which there are members of the government who act in an organized manner to enforce the law by finding, blocking, restoring, or punishing people who violate the laws and legal norms that govern the society where the law enforcement members are located.

The main objective of law enforcement is to create a sense of justice, legal certainty, and benefit in society. In this process, it must reflect aspects of justice and legal certainty and benefit.According to Barda Nawawi, there are 4 aspects of community protection that must also receive attention in criminal law enforcement, namely:

1) The community needs protection against anti-social actions that harm and endanger the community. Starting from this aspect, it is natural that law enforcement aims to tackle crime.

2) Society needs protection against someone's dangerous nature. Therefore it is also natural, if criminal law enforcement aims to improve the perpetrator of the crime or try to change and influence his behavior so that he is again obedient to the law and becomes a good and useful citizen.

3) Society also needs protection against abuse of sanctions or reactions from law enforcement and from society in general. Therefore, it is also natural that the enforcement of the criminal law must prevent the occurrence of arbitrary treatment or actions by the law.

4) Society needs protection against the balance or harmony of the various interests and values that depend as a result of crime. Therefore, it is also natural that criminal law enforcement must be able to resolve conflicts caused by criminal acts and bring a sense of peace in society.

In essence, law enforcement is carried out to realize ideals or principles that contain justice and truth. Law enforcement is not limited to the task of conventionally known law enforcers, but is the duty of everyone. However, in relation to public law, the government is the most responsible person.

Criminal disparity is the application of different crimes to the same crime. From this understanding, we can see that criminal disparities arise due to the imposition of different sentences for similar crimes. The imposition of this crime is, of course, a sentence imposed by the judge against the perpetrator of a criminal act so that it can be said that the role of the judge in case of criminal disparities is very decisive.

Judges 'decisions are a very important aspect in efforts to settle criminal cases, on the one hand, judges' decisions are useful for defendants to obtain legal certainty regarding their status, and at the same time they can prepare the next steps towards such decisions. 
According to Molly Cheang, as quoted by Muladi, "The disparity of the judge's decision or known as the disparity of sentencing will have fatal consequences, if it is linked to the administration of guiding prisoners. The convict, after comparing the crimes imposed on him and those imposed on other people, then feels that he is a victim of court uncertainty or disorder and will become a convict who does not respect the law, even though respect for the law is one of the results to be achieved in purpose of punishment".

But the reality is that in law enforcement against lottery gambling cases, there is injustice for the perpetrators who are brought before the court. Where in the same case there are disparities or differences in the decisions of the Panel of Judges. The results of the study in 2015 obtained data, the lightest verdict in the lottery gambling case was 1 (one) month in prison, while the heaviest was 1 year and 4 months in prison. The same chairman of the Assembly who decides a lottery case with a threat of 1 month in the same year decides the same case with a verdict of 10 (ten) months in prison. In 2016 the verdict on lottery gambling was the lightest 1 month 7 days and the heaviest 1 year 4 months. However, the judge who decided the most serious in 2016 also decided the same case with imprisonment of 1 month and 15 days. This means that the same judge still carries out disparities in the same case. In this case it is in accordance with Barda Nawawi's opinion that the communityrequires protection against abuse of sanctions or reactions from law enforcement. Therefore, it is also natural that the enforcement of the criminal law must prevent the occurrence of arbitrary treatment or actions by the law.

The public wonders why in the same case there are different decisions. In fact, the difference is very significant. The disparity in decisions against lottery gambling actors in law enforcement is one of the gaps in law enforcement. Law enforcement is a process to bring legal desires into reality. What is referred to as legal desires herein are none other than the thoughts of the legislature formulated in these legal regulations. The formulation of the thoughts of lawmakers as outlined in legal regulations will also determine how law enforcement is carried out. In reality, the law enforcement process culminates in its implementation by the law enforcement officials themselves.

Disparities in court decisions occur in courts. The disparity in the court's decision regarding the lottery gambling case at the Simalungun District Court is influenced by several external factors. One of the factors causing the disparity in decisions is due to the freedom of judges in deciding cases. This is in accordance with the provisions dArticle 24 Paragraph (1) of the 1945 Constitution affirms that judicial power is an independent power to administer the judiciary in order to uphold law and justice. . In essence, the freedom of the judge or the independence of the judiciary is intended to prevent abuse of authority and power by state bodies.

The existence of a judge's decision or commonly referred to as the term "court decision" is very necessary to resolve a case and provide a sense of justice, legal certainty and benefit. According to Sudikno Mertokusumo, a Judge's Decision is a statement made by the judge, as an authorized official, which is pronounced before the court and aims to end a case or dispute between the parties. In deciding a case a Judge must pay attention to all aspects in it, namely prudence, inaccuracy and negligence, both formal and material in nature to the proficiency in making it. Judges should be born and grow a moral satisfaction if the verdict he makes is used as a benchmark for the same case, and this decision does not become a topic of discussion for legal practitioners, even becomes research material for academics.

According to Dr. Lilik Mulyadi, SH, MH, a decision can be tested with 4 (four) basic criteria for questions (the 4 way test) in the form of: 
1. Is this my decision?

2. Am I honest in making decisions?

3. Is it fair for the parties concerned?

4. Is this my decision useful?

As a tool of analysis in this study, the theory of legal objectives proposed by Gustav Redbruch was used A German legal philosopher who teaches the existence of three basic ideas of law, by most legal theorists and legal philosophers, is also identified as three purposes of law, including justice, benefit and legal certainty.

According to Gustav Radbruch, justice, legal certainty, and benefits (Gerechtigkeit, Rechtssicherheit, Zweckmäßigkeit) are 3 (three) terms that are often chanted on campuses and courts. Two of these terms, namely justice and legal certainty, are at first glance contradictory, because it is very difficult to provide legal certainty as well as provide legal certainty in the same case, an example of the theft of Minah's grandmother's chocolate, but it may not be the case. The word justice can be an analogous term, so that the terms procedural justice, legalist justice, commutative justice, and so on are presented. Procedural justice, according to Nonet and Selznick, to mention one of the indicators of the type of autonomous law, for example, turns out that after being observed it leads to legal certainty for the sake of upholding the rule of law. So, in this context justice and legal certainty go hand in hand. Justice and certainty are 2 (two) axiological values in law.

In realizing the legal objectives, Gustav Radbruch stated that it is necessary to use the principle of priority of the three basic values which are the objectives of the law. This is because in reality, legal justice often collides with legal benefits and certainty and vice versa. Among the three basic values of the legal objectives, when a collision occurs, something must be sacrificed. For this reason, the principle of priority used by Gustav Radbruch must be implemented in the following order:

1. Legal Justice;

2. Legal Benefits;

3. Legal certainty.

From the order of priority as stated above, it is hoped that the legal system can avoid internal conflicts and conflicts of interest. Historically, according to Gustav Radbruch, the goal of certainty was at the top of the list among the other goals. This aims to avoid the arbitrariness of the authorities. However, after seeing the fact that with his theory Germany under Nazi rule legalized inhumane practices during World War II by making laws legalizing the atrocities of war at that time, Radbruch finally corrected his theory above by placing the goal of justice above other legal objectives such as legal certainty and legal benefit.

As one of the objectives of law, legal certainty can be said to be part of the effort to achieve justice. The real form of legal certainty is the implementation or enforcement of an action regardless of who did it. This is in accordance with the principle of all people having an equal position in law (equality before the law). With legal certainty, everyone can analyze or find out what will be experienced if they take certain legal actions. Legal certainty is needed to realize the principle of equality before the law without discrimination and is an inherent feature of law, especially for written legal norms. Law without certainty values will lose its meaning because it can no longer be used as a code of conduct for everyone. The word "certainty" is closely related to the principle of truth, which is something that can be strictly legally-formally syllogized. Through deductive logic, positive law rules are placed as major premises, while concrete events become minor premises. Through a closed logic system, conclusions can be obtained immediately. The conclusion obtained must be something that can be predicted, so that everyone is obliged 
to stick to it. With this handle, society becomes orderly. Therefore, certainty will lead society to order.

Furthermore, Gustav Radbruch stated 4 (four) fundamental things related to the meaning of legal certainty, namely:

1. That law is positive means that positive law is legislation.

2. That law is based on facts, meaning that it is based on reality.

3. That the facts must be formulated in a clear manner so as to avoid confusion in meaning, as well as being easy to implement.

4. Positive laws cannot be easily changed.

According to Gustav Radbruch 3 (three) aspects are relative, meaning they can change. At one time it could highlight justice by placing the utility and legal certainty to the periphery. But at other times it can highlight legal certainty by ignoring justice and benefit. But it can also highlight benefits by ignoring justice and certainty. This relative and volatile relationship is unsatisfactory. Meuwissen chose freedom as the basis and ideals of law. The freedom that is meant is not arbitrary, because freedom has nothing to do with what we want. But with regard to wanting what we want. With freedom we can relate certainty, justice, equality and so on instead of following Radbruch.

If every decision is taken by the judge by referring to the questions above, then the legal objectives as taught by „,,, can be answered. Thus, this decision provides a sense of justice for the community, because there is no disparity in decisions regarding the same case, as well as the achievement of legal certainty and moreover this decision benefits the parties in particular and the general public in general.

\section{Conclusion}

The court verdict on the same case, namely against lottery gambling there is a difference or disparity. The difference or disparity in this decision is due to external factors. Besides that, it is also due to the freedom of a judge in deciding a case.

The implementation of freedom of judges in deciding a case is that the judge is free from interference by other powers. However, in deciding a case, the judge should test the decision against 4 basic criteria. So it is hoped that the decision will provide a sense of justice, legal certainty and benefit to the community.

\section{References}

Achmad Ali.(2010). Menguak Teori Hukum (Legal Theory) \& Teori Peradilan (Judicialprudence) Termasuk Undang-Undang (Legisprudence) Volume I Pemahaman Awal, Kencana Prenada Media Group, Jakarta.

Ahmad Zaenal Fanani, (2011). Berpikir Falsafati Dalam Putusan Hakim, Artikel ini pernah dimuat di Varia Peradilan No. 304 Maret.

Arief Sidharta. (2008). Meuwissen Tentang Pengembanan Hukum, Ilmu Hukum, Teori Hukum dan Filsafat Hukum, PT Refika Aditama, Bandung,

Barda Nawawi Arief. (1998). Beberapa Aspek Kebijakan Penegakan dan Pengembangan Hukum Pidana, PT. Citra Aditya Bakti, Bandung.

Carl Joachim Friedrich. (2004). "Filsafat Hukum Perspektif Historis, Nuansa dan Nusamedia. Bandung.

Dahlan. (2017). Problematika Keadilan Dalam Penerapan Pidana Terhadap Penyalahgunaan Narkotika, CV Budi Utama, Yogyakarta. 
Frans Magnis Suseno, Etika Politik : Prinsip- Prinsip Moral Dasar Kenegaraan Modern, Jakarta

Lilik Mulyadi. (2015). Seraut Wajah Putusan Hakim dalam Hukum Acara Perdata Indonesia Perspektif Teoritis, Praktik, Teknik Membuat, dan Permasalahannya, PT. Citra Aditya Bakti: Bandung.

Marsella, E and Dian, P. (2020). Folklore as Ethnic Embodiment Bias: Value Analysis on Karo Folklore. Budapest International Research and Critics Institute-Journal (BIRCIJournal). 2619-2628

Muhammad Erwin. (2012). Filsafat Hukum, Raja Grafindo, Jakarta.

Muladi \& Barda Nawawi Arief. (1984). Teori-teori dan Kebijakan Pidana, Cetakan Kedua, Bandung.

New Law Journal - Volume 123, Part 1, hal. 358, 1974

Pokok - Pokok Analisa Laporan Keuangan. BPFE, Cetakan I, Yogyakarta.

UUD 1945

UU Nomor 73 tahun 1958, tentang Menyatakan Berlakunya UU Nomor 1 tahun 1946 Republik Indonesia tentang Peraturan Hukum Pidana Untuk Seluruh wilayah Republik Indonesia dan Mengubah Kitab Undang-Undnag Hukum Pidana. https://lektur.id/arti-judi/ 